\title{
UKRAINIAN LOCAL CHURCH: REALITIES OF THE PROCLAMATION AND PROSPECTS
}

\author{
Andrii Kobetiak \\ Ph.D. in Philosophy, Doctoral Student, Zhytomyr Polytechnic State University, Ukraine \\ e-mail:kobetiak@meta.ua, orcid.org/0000-0001-6899-0571
}

\begin{abstract}
Summary
The article analyzes the process of formation of the newly formed Local Ukrainian Church at the present stage. It is determined that the institutional design of the Orthodox Church of Ukraine takes place in a multi-religious environment. Therefore, the article predicts that today in Ukraine, there is no reason to talk about the United Church in the future. It is determined that the Ukrainian church issue is a kind of watershed in terms of the main controversial issues that have troubled the Ecumenical Church in recent centuries. Therefore, it has been proved that the settlement of the Ukrainian question is of great importance not only for the Orthodox believers of Ukraine, but also for the whole Orthodoxy. Most countries that have received autocephaly in our time have been waiting for decades for world recognition of their own church. Therefore, the recognition of the Orthodox Church of Ukraine by only a part of the Local Churches is a natural process. It is established that autocephaly in modern conditions of society development and hybrid war is a vital condition for the country's survival. It has been studied that in modern conditions the Kyiv Church has received a great credit of trust in the eyes of the Ecumenical Patriarch. The consolidated Kyiv metropolitanate may become the largest national Orthodox church in the world, which will significantly change the balance in the structure of the Universal Orthodoxy.
\end{abstract}

Keywords: Ukrainian Church, autocephaly, metropolitan, religion, local council, society, interfaith relations.

DOI: https://doi.org/10.23856/4706

\section{Introduction}

Today, the religious sphere occupies one of the leading places in the life of modern Ukrainian society. Our people have always had a high level of religiosity, therefore religious issues are especially close and important to most citizens. At the beginning of the 21 st century, the religious situation is such that Orthodoxy, which is the dominant religion in the country, is divided into two jurisdictions. The Ukrainian Orthodox Church, which is subordinate to the Moscow Patriarchate, and the Orthodox Church of Ukraine, which in early 2019 received a Tomos on autocephaly. There is no doubt that one of the most important achievements since the independence of Ukraine is the acquisition of autocephalous status by the Ukrainian Church. Historically, this event has taken place very recently, but it is crucial for the formation of a new Ukrainian civil society, the strengthening of the foundation of independence, and is a key issue for national security. In addition, the autocephalous status of the church clearly contributes to the growth of Ukraine's authority in the international arena.

The relevance of the studied problem today is caused by a significant public resonance around the covered issue. Moreover, the issue of the Ukrainian Church touches on a number of problems of the Universal Orthodoxy and relations between the Local Churches, which have been troubling the church for the last century and do not have the prospect of an immediate solution. 
The constitution of the Ukrainian Church is directly related to the problems of the formation of a new autocephalous church; superiority in the diptych; bounds of the canonical territory; general jurisdiction and problems of the relationship between the mother church and the daughter church; Orthodox diaspora. So, the relevance of the topic for research is beyond doubt, because it is caused by significant Ukrainian and global interest in the issue of proclaiming a new Local Church, as well as a number of unresolved issues of Ecumenical Orthodoxy.

As for the scientific development of the topic, it is immediately worth noting that this is a new topic for discussion at first glance. The Local Ukrainian Church was formed only in 2019, so there is no fundamental research regarding it. Most materials are presented in public speeches, statements, documents. However, the autocephalous movement in Ukraine is about a hundred years old. Domestic researchers were especially interested in the issue of the United Ukrainian Local Church after the proclamation of state independence in 1991.

On the one hand, there are hundreds of public statements, speeches and official letters from hierarchs and theologians from various Local Churches, but most of them has a polemical nature. On the other hand, public interest in the issue of the unity of Orthodox churches in the face of civilizational challenges has become much more active. Such a surge of interest in the problem of autocephaly is undoubtedly associated with the proclamation of 15 in the diptych of the autocephalous church, namely the Orthodox Church of Ukraine.

Especially valuable are the works of the researchers of Ukrainian church history and the canonical structure of the Orthodox Church I. Vlasovsky, O. Kyridon, O. Lototsy, Y. MulykLutsyk and others. Relevant today is the work of the famous fighter for the independence of the Ukrainian Church, Metropolitan Alexander (Drabinko) "Ukrainian Church: the path to autocephaly", in which the author in-depth reveals the way to implement various concepts of autocephaly of the Ukrainian Church in the twentieth century (Oleksandr (Drabynko), 2018). It is necessary to mention the work of V. Butynsky on the jurisdiction of Ukrainian Orthodoxy and the possibility of canonical formation of the Local Church (Butyns'kyy, 2014) and M. Gergelyuk on the canonical and ecclesiological foundations of the autocephalous structure of churches in the Ecumenical Orthodoxy (Herhelyuk, 2014). In general, the works of such philosophers, theologians and theologians as: D. Gorevoy, V. Yelensky, O. Sagan, L. Filipovych, Y. Chornomorets and others are devoted to the religious analysis of the processes of obtaining autocephaly. Of importance for this study are the work of A. Aristova on ways to resolve religious conflicts, as well as P. Saukha on religious experience and the phenomenology of religion.

The purpose of the article is to analyze the state and prospects of development of the Orthodox Church in Ukraine, its institutionalization and religious and ideological activities in Ukraine in modern historical conditions as well as in the nearest future.

\section{The main text}

\subsection{World confrontation and Ukraine}

The problematic field of proclamation and further recognition of the OCU covers a whole set of key issues for the entire Orthodox Church. The Ukrainian question is a kind of watershed in terms of the main controversial issues that have troubled the Ecumenical Church in recent centuries. First of all, this is the question of autocephaly and the procedure for its recognition, the Orthodox diaspora and its jurisdiction, the dissolution of Eucharistic communion, and in general this calls into question the functioning of order in the diptych and the relationship of individual Local Churches.

Not much time has passed since Tomos was granted. Today, each of the world's Orthodox hierarchs and well-known theologians takes their own position on support or rejection of the 
OCU, while someone still takes a neutral position on this issue, but, obviously, two opposite camps are being formed - the pro-Moscow one, and the one that supports the decision of the Ecumenical Patriarchate. It is the confrontation between the Patriarchates of Constantinople and Moscow that significantly complicates the positive solution of the Ukrainian question. The centuries-old "competition of glory" between Moscow and the Ecumenical Patriarch has repeatedly touched on the Ukrainian issue (Knyha pravyl 2010: 88). On the other hand, in religious matters concerning Ukraine, one cannot consider the problem of the confrontation between the patriarchates in the two-dimensional plane of Constantinople-Moscow. The struggle of the Kyiv Patriarchate for its own recognition and independence is more relevant for the Ukrainian land. This is not about a specific religious organization "Ukrainian Orthodox Church of the Kyiv Patriarchate", which was formed in 1992, but about the struggle of the authentic Kyiv metropolis, the Ukrainian church itself, for the right to exist in its own country. Well-known modern theologian Archimandrite Kyrylo Hovorun claims that the Ukrainian autocephalous movement is over 100 years old (Kyrylo (Hovorun), 2019).

It is worth to mention that the institutionalization, ie the social design of the church, its formation, takes place under the conditions of the Russian-Ukrainian war. The Russian Federation opposes the newly created OCU and everything Ukrainian, in particular the national self-identification of our fellow citizens, on two main fronts. The first one is the open war in Donbass and the annexation of Crimea. On the annexed Ukrainian territory Russia is openly destroying everything connected with the national roots of Ukrainians. The Ukrainian Orthodox Church, with the exception of the release of several prisoners of war and public figures from captivity, stands aside (Poloneni na Donbasi). The second front is an ideological one. Through the mediation of the Moscow Patriarchate in Ukraine there is a substitution of concepts. They are trying to take away ukrainian historical heritage. Sometimes we hear that Moscow received Baptism from Byzantium, or that Kyiv has always belong to Russia. In fact, these are pretty obvious things. Without Kyiv, the Moscow Church has no ancient history, without Ukraine it loses its historical significance, and hence its weight in the international arena. It is no longer even a question of the fact that the UOC today is almost half of the total ROC. Another thing is important, as in Ukraine, local priests and believers are sometimes guided by the interests of distant Russia, rather than the problems of local communities, the local Christian community (Oleksandr (Drabynko), 2018: 28). It is important that the people unite and unanimously confront the aggressor. After all, Russia cannot consider itself the successor of Kyivan Rus if Kyiv does not enter its territory, at least under ecclesiastical subordination. Therefore, the question remains open. Russia will try to keep Ukraine in the field of ideological influence as much as possible.

\subsection{The problem of "Russian world" in the 21 century}

This is largely due to the concept of the "Russian world" proposed by the current Patriarch Kirill. They started talking about the "Russian world" relatively recently - in the middle of the 2000s. It was during these years that many of Ukrainians began to show a special interest in studying the spiritual and cultural heritage of the Russian emigration. Descendants of emigrants of different waves began to show an increased interest in Russia too.

The theme of the "Russian world" has become widespread in the church environment. Thus, Patriarch Kirill actively used it in a number of his speeches and sermons, mainly in the first years of his patriarchate. Especially often the Patriarch spoke about the "Russian world" during his trips to Ukraine and to Belarus, substantiating with the help of this concept the idea of the unity of the fraternal Slavic peoples of a once united country. However, the very concept 
of the "Russian world" is still not developed in detail, although both in the secular and in the church environment, certain attempts have been made to formulate its main, basic principles.

In contrast, the representative of the OCU, Bishop Evstratii (Zorya), gives the following description: "The concept of the 'Russian world' is in fact a modernized version of the traditional Russian imperial idea. And this idea, in turn, cannot be realized without Ukraine. Therefore, the "Russian world" in any of its variants is explicitly or implicitly hostile to the Ukrainian national idea, Ukrainian statehood. Recently, the activity in the implementation of this idea has shifted from the religious and cultural component to the political and economic one (Fihurnyy, 2016).

However, one should not idealize and exaggerate the possibilities of the "Russian world" as a general concept, which supposedly is the main enemy of the Ukrainian people. Representatives of the OCU, and some scholars too, overestimate the concept's influence on the Ukrainian population. In practice, in modern conditions, its implementation looks rather illusory. Proof of this is the data of one of the latest sociological polls, according to which more than $80 \%$ of Ukrainian citizens have never heard of the concept of the "Russian world" from Patriarch Kirill at all, and of those who have heard something about it, 3/4 consider it to be only a modernization of the imperial idea and treat it negatively (Yablons'kyy, 2014: 36).

Today it is important to create the necessary canonical and legislative framework, which has just begun to be implemented, for example, Law No. 5309 on the need to rename churches, the governing center of which is located outside Ukraine in a state recognized as an aggressor country. It is obvious that first of all it concerns the UOC-MP. It is necessary to engage in educational work so that pro-Moscow sentiments do not further take root in Ukrainian society and do not affect the processes of self-identification of Ukrainian citizens.

It is obvious that the events around the Tomos have significantly aggravated the vector of the church confrontation Kyiv-Moscow, and gave impetus to a new wave of the long-standing struggle between Moscow and Constantinople. In addition, Russia's aggression in the Donbass and the annexation of Crimea add a significant political tint to the "church politics" in Ukraine. The presence of the Russian Orthodox Church in Ukraine plays an important role in this. Therefore, the fastest possible unification of the Orthodox churches divided today into different jurisdictions will contribute to the consolidation of the Ukrainian nation. It is necessary to clearly understand that the absolute majority of the parishioners of the UOC of the Moscow Patriarchate are ordinary ukrainian citizens who love their nation, their country (Ukraine), do not engage in various political and church scams, and, moreover, do not support the hostile and aggressive policy of the Kremlin and the war in the East (Oleksandr (Drabynko), 2014: 35). A significant number visit the churches of this confession even today only because it is either the faith of their parents, or there is no other church in the town or village, or this is already a tradition. Perhaps they just got used to going to this particular temple, to this place, for example, because there is a playground for children or the service begins later. There can be many reasons. Most of them are indeed objective ones. There are also wonderful priests in the UOC who have nothing to do with the "Russian world" and everything like that. They are excellent missionaries, faithful shepherds of their believers. One should not equalize everyone under the same denominator. Of course, in its leading echelon, the Moscow Patriarchate contributes to the deployment of Russian aggression, at least by passive silence and non-recognition of the ongoing war.

\subsection{State-church relations in Ukraine}

It is important to note that the state and church boundaries must coincide. This facilitates state-church relations and relations between Local Churches. This is the ideal of the Ecumenical arrangement to which the church should approach. However, this does not mean that the state 
should conquer the church and use it as its own instrument of influence. At the same time, the church is called to "save souls" and meet the needs of all citizens of the state, not in the national, but in the civil sense (Butyns'kyy, 2014:85).

The reaction of the Ecumenical Patriarchate to the appeal of the President and the Verkhovna Rada of Ukraine was relatively quick. In 2018, the Patriarchate of Constantinople supported the process of creating a single autocephalous Orthodox Church of Ukraine. On December 15, the hierarchs of three Orthodox churches - the Ukrainian Orthodox Church - the Kyiv Patriarchate, the Ukrainian Autocephalous Orthodox Church and the Ukrainian Orthodox Church (Moscow Patriarchate) - at a joint council united into a church, to which Patriarch Bartholomew of Constantinople granted the Tomos of autocephaly.

Thus, the Ukrainian Church is not only gaining independence from the Moscow Patriarchate, but will also receive recognition by other churches, taking its place in the diptych the list of Orthodox autocephalous and autonomous churches.

The new autocephalous Orthodox Church of Ukraine is the heir to the Kyiv Metropolis of the Patriarchate of Constantinople, but does not inherit its historical boundaries. The jurisdiction of the Ukrainian Church extends to Ukraine within its modern internationally recognized borders. This follows from the fact that church organizations adapt primarily to modern administrative and political realities, although they take into account historical realities as well.

\subsection{The problem of further recognition}

Today the fate of the Kyiv metropolitanate seems to have been decided, autocephaly has been proclaimed. Although there is a fact, so far only four out of fifteen Local Churches have officially recognized the Orthodox Church of Ukraine and its Primate with the election. Currently, this issue is difficult and there is no immediate solution. On the one hand, we can cite the statement of the professor of the University of Thessaloniki A. Vavuskos that the granting of autocephaly by the Ecumenical Patriarch does not require ratification due to historical precedent and custom, which is equated to the norms of canon law (Vavuskos).

In order to be a full-fledged Local Church, according to the modern world-renowned theologian I. Zizioulas, a full-fledged Eucharist must take place with all the churches. It is not enough to be Local, ie to be located in a specific area, it is necessary to be in full communication, otherwise there is a phenomenon of "imperfection of the church" (Zyzyulas, 2005:495).

In particular, in a situation of lack of theological unity, a sign of unity between the Local Churches is the joint ministry of the Eucharist. It takes place during joint solemn events, when primates and representatives of various Local Churches gather around the service of the liturgy. Kyiv was a repeated witness of such celebrations of Eucharistic communion - in particular, during the anniversaries of the baptism of Kyiv Rus (Bortnyk, 2020:108).

It is pertinent to note the fact that in the Orthodox Church in moments that are not directly regulated in the canons, a precedent is a strong argument. It is now clearly seen that the Churches of the Greek tradition in the difficult process of recognizing the Tomos of autocephaly of the Orthodox Church of Ukraine have already formed this precedent regarding the "form" of recognition. Consequently, "both in the Church of Greece and in the Alexandrian Patriarchate, which were the first to join the recognition of the OCU, it was determined that the right to recognize the new autocephalous Church, which was granted the Tomos by the Ecumenical Patriarch, is the right of the Primate. Not the Synod or any other governing body, but the Primate of the Church" (Spetsial'no dlya).

Turning to the history of the formation of diptychial, that is, officially mutually recognized local Orthodox churches, in the history of Ecumenical Orthodoxy, three large periods of granting 
autocephaly can be distinguished. The first is ancient, when the faith spread, new metropolises were founded. This is how the first, so-called, ancient patriarchates were formed: the Roman patriarchy, with which there was a division in 1054, Constantinople, Alexandria, Antioch and Jerusalem. All of them are approved by the authority of the Ecumenical Councils and are mentioned in the corresponding canons and council documents (Knyha pravyl). It is important that these churches, in fact, were not granted the status of autocephaly. They are approved by the Councils as already existing and autocephalous. For example, to the Jerusalem Church, Jesus Christ himself supplies the first bishop Jacob, his brother according to Joseph the Betrothed. Their status and weight in the Orthodox world has never been in doubt. The authority of these churches is extremely high today. The second is the elevation of the Moscow Church to the rank of Patriarchate in 1589. The time difference between the Ecumenical Councils and the patriarchal status of Moscow is about 1000 years. Significant changes have taken place in church and world history. Ancient patriarchies are losing state independence and weight in their countries (Byzantium has disappeared altogether). Religiously, they continue to occupy the first places in the diptych, but in the political and global meaning they play an ever smaller role. And the third is the period of new autocephalous churches. 9 churches, and from the American 10 have received full independence over the past 150 years. Each of the newly proclaimed autocephaly in turn takes a certain place in the diptych. Regarding the American OC, the situation remains unresolved today, because this problem is closely intertwined with the design of the Orthodox diaspora and the boundaries of the canonical territory, which is ecclesiologically and canonically unreasonable so far. Although this issue was repeatedly discussed at the Pre-Council meetings and at the Great Council of Crete in 2016, and the corresponding document on the procedure for the registration of the diaspora was adopted, the situation remained unresolved (Dokumenty, 2016: 61-70). Today, the question arises in such a way that the American OC can be recognized in the event that other Local Churches refuse from parishes in the diaspora. And this is additional funds and a variety of incoming assistance.

Despite the above historical stages of the formation of the modern structure of the Universal Orthodoxy, today there is no agreed and approved document on the procedure for the formation of a new Local Church. In other words, the granting of Thomoses and the proclamation of the autocephalous status of the newly formed churches is an unregulated process, despite the existence of the Orthodox Church's own church code and its two-thousand-year of history. And also, despite the already significant number of historical precedents (Herhelyuk, 2014:39). In addition, the experience of proclaiming already recognized Local Churches, although is different, testifies to the impossibility of forming autocephalous church structures by declaring the existing state of affairs. That is, the Ecumenical Patriarchate or Synaxis (a meeting of the Primates) cannot simply state the existence of a certain church as autocephalous. Since there is no concept of obtaining such a status, at different times different Local Churches received differently church-wide recognition. Therefore, an ambiguous conflict arises. On the one hand, purely objective facts indicate the absence of a procedure for proclaiming autocephaly in the norms of canon law, and on the other, subjective historical political reasons, including the opposition of the Moscow and Constantinople Patriarchates, affect the development and signing of such a document.

\subsection{Unresolved issues}

Despite the numerous achievements of the newly formed church and the significant historical path of the formation of Kyiv Orthodoxy, it should be stated that an integral concept, a general doctrine of the Ukrainian Church, which could single-handedly identify itself with the ancient Kyiv cathedra, which is the direct heir of Byzantium, has not been formalized yet. This 
is evidenced by the letter of Patriarch Volodymyr (Romanyuk) to the President of the Academy of Sciences B. Paton with a request to help find the origins and national characteristics of the Kyiv Church (Sahan, 2004:634). Over the years of Ukraine's independence, the situation has not changed dramatically. This is evidenced by the division of Ukrainian Orthodoxy. Moreover, this trend will potentially continue in the coming decades. Of course, during the years of Ukraine's independence, Orthodoxy was unambiguously constitutional within the state. In 2019, the Ukrainian Church received the long-awaited Tomos on Independence, but as for now, according to the official statistics from the State Service for Ethnopolitics and Freedom of Conscience in 2021 , less than half of all Orthodox parishes belong to the newly formed religious organization. 7188 registered communities belong to the OCU, while 12406 belong to the UOC-MP (Zvit pro merezhu, 2021). Thus, it testifies to the identification disunity of Ukrainian believers. Autocephaly did not become a panacea for separation. The UOC-MP continues to dominate the confessional section of Ukraine. It is difficult to say whether this will lead to an escalation of the conflict in the East and to inter-religious confrontations. Hybrid warfare always carries a hidden danger. Therefore, the country's religious security today is one of the key tasks of the national security of Ukraine and the potential construction of civil society in our country.

Public support for the granting of the Tomos by the Constantinople (Ecumenical) Patriarchate at the end of 2020, has not changed, compared to 2019. However, among the faithful to the $\mathrm{OCU}$, the corresponding figure is $62 \%$; only $17 \%$ of respondents do not support the provision of Tomos from Constantinople; $50 \%$ are indifferent to this event or have not decided on their attitude to it (Osoblyvosti, 2020:6).

The new Ukrainian Church is finally becoming Orthodox in its essence and pro-Ukrainian in its inner content. The main thing is that in the new church organization there should be more Christian and the church proper, whilr less nationalistic and hostile to dissidents. Tolerance is the only path to reconciliation and unification. Guarantee of peace in the present situation - popular Orthodoxy, an open one. For this, the hierarchy must forget about its leading ambitions and serve the Ukrainian people. It is in Ukraine, and not in Byzantium or the Russian Empire, that there are all the preconditions for building symphonic interaction between the state and the church.

Historically, Ukraine is a place of intersection of the sphere of influence of the "three Romans". This confrontation has clearly intensified with the granting of the Tomos to Ukraine by the Ecumenical Patriarch. There is a hope that the conflict will be resolved peacefully, that this situation, on the contrary, will go to the common Orthodox benefit. Several more churches are waiting for autocephaly and world recognition, therefore, the Ukrainian example is an important precedent in dogmatic and canonical work. We need to return to the ancient traditions of the Kyiv Church, which was as open and tuned to the Universal understanding of inter-church interaction.

\section{Conclusions}

Considering the above, the newly proclaimed and already independent Ukrainian Church has significant potential. This is a historical challenge: will it be able to unite society, will it be attractive to young people, will internal hierarchical feuds and the "struggle for spheres of influence", which have not allowed for centuries to be united and independent, recede into the background. Time will help to judge, but today, as never before, the Kyiv Church has received a great credit of trust in the eyes of the Ecumenical Patriarch. Today it is necessary to unite for the future recognition of the Ukrainian status by other Local Churches. The consolidated Kyiv Metropolitanate may become the largest national Orthodox church in the world, which will 
significantly change the balance in the structure of Ecumenical Orthodoxy. This is the main reason for the opposition of the ROC and some Local Churches to the Ukrainian association. Therefore, it is important for Ukrainians to remember that the jurisdictional division is artificial and is supported by the enemies of independent Ukraine. It is a time of reconciliation and tolerance.

In general, the Inter-Orthodox crisis, like the Pan-Orthodox Council, has shown that there are significant problems within the Orthodox Church. The Ukrainian situation became a litmus test, which demonstrated that not everything is so good in the Universal United Orthodox Church. That in fact there are serious and outdated problems in the Inter-Orthodox relations. It is necessary to find ways to overcome the pan-Orthodox crisis, which the Ukrainian Church only designed and did not cause.

Today, the OCU is not the only Orthodox denomination in Ukraine, so believers will not visit its churches "out of desperation and no alternative." There must be healthy competition, and the OCU has to show its best side.

In addition to the ideas of state-strategic importance and a serious influence on the formation of the independent consciousness of our compatriots, the proclamation of the status of autocephaly of the Ukrainian Church has one more, perhaps the most important task - to cure the schism. Millions of Ukrainian believers, thousands of priests were out of communication with the world Orthodoxy. Today there are no "schismatics" in Ukraine, and this is the main achievement of Tomos. A united, spiritually strong and independent Church of Ukraine should be the foundation of a new Ukrainian nation, for only the autocephalous system of the Ukrainian Church can restore trust between society and the church structure, between believers and clergy, between the state and the Church.

\section{References}

1. Bortnyk S. (2020). Stratehiya prymyrennya. Rol' tserkov v Ukrayini [Strategy of reconciliation. The role of churches in Ukraine]. Kiev. [in Ukrainian].

2. Butyns'kyy V. (2014). Yurysdyktsiynyy status ukrayins'koho pravoslav"ya i perspektyvy kanonichnoho oformlennya pomisnoyi tserkvy: relihiyeznavchi ta ekleziolohichni refleksiyi (1991 - 2013 rr.) [Jurisdictional status of Ukrainian Orthodoxy and prospects of canonical design of the local church: religious and ecclesiological reflections (1991-2013). Chernivtsi. [in Ukrainian].

3. Vavuskos A. Should Tomos on Autocephaly issued by the Ecumenical Patriarchate be ratified by local churches? URL: https://cerkvarium.org/ru/publikatsii/monitoring-smi/ dolzhny-li-tomosy-ob-avtokefaliyakh-vydannye-vselenskim-patriarkhatom-ratifitsirovatsya-pomestnymi-tserkvami.html.

4. Herhelyuk M. (2014). Kanonichni ta ekleziolohichni zasady avtokefal'noho ustroyu tserkov u strukturi Vselens'koho pravoslav"ya: istorychnyy kontekst [Canonical and ecclesiological principles of the autocephalous system of churches in the structure of the Universal Orthodoxy: historical aspect] (PhD Thesis). Chernivtsi: Chernivets'kyy natsional'nyy universytet imeni yuriya fed'kovycha.

5. Dokumenty Svyatoho i Velykoho Soboru Pravoslavnoyi Tserkvy [Documents of the Holy and Great Council of the Orthodox Church]. (2016). 112 p.

6. Zvit pro merezhu relihiynykh orhanizatsiy $v$ Ukrayini stanom na 1 sichnya 2021 roku [Report on the network of religious organizations in Ukraine as of January 1, 2021$].$ URL: https://dess.gov.ua/statistics-2020. 
7. Zyzyulas Y. (2005). Samoponymanye pravoslavnykh y ykh uchastye v ékumenycheskom dvyzhenyy: mezhpravoslavnaya konsul'tatsyya ob otnoshenyy ko Vsemyrnomu Sovetu Tserkvey Shambezy (Shveytsaryya, 19-24 yyunya 1995 h.) [Self-understanding of the Orthodox and their participation in the ecumenical movement: an inter-Orthodox consultation on the attitude to the World Council of Châmbezi Churches]. Pravoslavye y ékumenyzm.

8. Kyrylo (Hovorun), arkhimandryt. (2019). Pomylka Patriarkha. Misto. URL: http://lenta.te.ua/ society/2019/01/12/101033.html.

9. Kolodnyy A. (2009). Relihiyne s'ohodennya Ukrayiny: rozdumy, otsinky i prohnozy (tematychna zbirka vybranykh statey $i$ tez) [Religious present of Ukraine: reflections, assessments and forecasts (thematic collection of selected articles and theses)]. Kiev. [in Ukrainian].

10. Knyha pravyl Svyatykh Apostol, Svyatykh Soborov Vselenskykh y Pomestnykh y Svyatykh Otets [Book of rules of the Holy Apostles, the Holy Councils of the Ecumenical and Local and the Holy Fathers]. (2010). Moscow.

11. Oleksandr (Drabynko), mytropolyt. (2018). Ukrayins'ka Tserkva: shlyakh do avtokefaliyi. Do dyskusiyi navkolo kanonichnoho statusu, bohosluzhbovoyi movy ta istoriyi Ukrayins'koyi Tserkvy [Ukrainian Church: the path to autocephaly]. - Kiev. DUKH I LITERA. [in Ukrainian]. 12. Osoblyvosti relihiynoho i tserkovno-relihiynoho samovyznachennya hromadyan Ukrayiny: tendentsiyi 2000-2020rr. (Informatsiyni materialy) Razumkov centre. Kiev (2020).

13. Poloneni na Donbasi i Moskovs'kyy patriarkhat. Shcho mozhe zrobyty tserkva? [Prisoners in the Donbass and the Moscow Patriarchate. What can the church do?]. interv'yu L. Fylypovych ta A. Yurasha. URL: https://www.radiosvoboda.org/a/28185932.html.

14. Sahan O. (2004). Vselens'ke pravoslav'ya: sut', istoriya, suchasnyy stan [Ecumenical Orthodoxy: essence, history, current state]. Kiev: Svit Znan. [in Ukrainian].

15. Spetsial'no dlya UPTS MP rechnyk PTSU poyasnyv, shcho oznachaye vyznannya Kiprom [Especially for the UOC-MP, a spokesman for the PCU explained what it means to recognize Cyprus]. URL: https://religionpravda.com.ua/? $p=57945$.

16. Fihurnyy YU. (2016) Stan i perspektyvy rozvytku Pravoslavnoyi Tserkvy v Ukrayini na rubezhi XX-XXI st. ta $v$ umovakh hibrydnoyi rosiys'ko-ukrayins'koyi viyny [The state and prospects of development of the Orthodox Church in Ukraine at the turn of the XX-XXI centuries. and in the conditions of a hybrid Russian-Ukrainian war]. Pravoslav"ya v Ukrayini : Zbirnyk materialiv VI Mizhnarodnoyi naukovoyi konferentsiyi. Kiev. P. 864-886.

17. Yablons'kyy V. M.; Zdioruk S. I.; Tokman V. V; Astaf'yef V. V.; Valevs'kyy O. L.; Zubchenko S. O.; Ishchenko A. YU.; Lytvynenko O. M. (2014). Ukrayina ta proekt «Russkoho Myra» [Ukraine and the project "Russian World"] Analitychna dopovid. Kiev. P. 32-41. 